\title{
William Morris Davis e a Teoria Geográfica
}

\author{
Carlos Augusto de Figueiredo Monteiro \\ Universidade de São Paulo \\ email: casusto@uol.com.br
}

Artigo convidado recebido em 15 de maior de 2001

\begin{abstract}
RESUMO
O autor põe em confronto a proposta teórica do Ciclo Geográfico de W. M. Davis, da virada dos séculos passados (1899) e a famosa crítica sobre a carência de fundamentação científica na Geografia, feita por Fred Schaefer (1953). Este é o ponto de partida para traçar um panorama da evolução da Geografia Física no Brasil, notadamente da Geomorfologia e da Climatologia, ao longo do século XX. Sincronizando a evolução do pensamento geográfico com os grandes acontecimentos mundiais do passado século, o autor destaca o segmento 1968-1973 como o possível ponto de mutação a partir do qual penetramos na Grande Crise Histórica que atravessamos nesta virada dos séculos XX e XXI e o caráter desagregativo da atual Geografia.
\end{abstract}

Palavras chave: Teoria Geográfica, Geomorfologia, Brasil, Século XX.

\begin{abstract}
The author promotes a confrontation between the W. M. Davis' “The Geographical Cycle" (1899) and Fred Schaefer's "Excepcionalism in Geography" (1953). This is taken as the starting point for an overview of the theoretical evolution in geomorphology and climatology within the scope of Physical Geography produced in Brazil during the XX ${ }^{\text {th }}$ Century. In this analysis the author emphasizes the period $1968-1973$ as a possible turning point toward to the great historical crises in which we are drowned at this threshold of the new millennium and the astonishingly desegregation of todays Geography.
\end{abstract}

Keywords: Geographical Theory, Geomorphology, Brazil, $\mathrm{XX}^{\text {th }}$ Century.

\section{Introdução}

Minha presença neste simpósio ${ }^{1}$ não é aquela do geomorfólogo atuante que vem confrontar e debater idéias com seus colegas. Trata-se, antes, da presença de um geógrafo (ou melhor, de um aprendiz de geógrafo) que, malgrado haver sido impelido à pesquisa em Climatologia, sempre procurou considerar a Geografia como uma convergência holística da relação Homem/Natureza. Atraído pela História ao ingressar na Faculdade Nacional de Filosofia, da antiga Universidade do Brasil, no Rio de Janeiro, nos idos de 1947, em pouco tempo fui capturado pela Geografia. E, nesse campo, a Geomorfologia foi o meu primeiro ímã. As circunstâncias, várias, quem sabe o acaso, impeliram-me para a pesquisa em Climatologia, área bem mais carente, entre nos, na metade do século que expira.

\footnotetext{
${ }^{1}$ Palestra ministrada no III Simpósio Nacional de Geomorfologia, Campinas, de 3 a 6 de setembro de 2000 .
}

Desde que encerrei minha carreira acadêmica, na docência e pesquisa, venho sendo chamado para eventos geográficos nos quais me tenho obstinado a fruir deles como meio de informação e, quando instado a participar neles, ater-me ao papel de alguém que, havendo encerrado sua militância, limita-se a depor à base de reflexões sobre a sua experiência passada. Neste encontro, além daqueles dois propósitos, moveme o desejo de rever colegas e amigos, inclusive com a honrosa incumbência de apresentar alguns dos homenageados no certame.

Ao propor-me tratar de William Morris Davis, não desejo“exumá-lo para um possível revival a modo do que acontece, no momento, com outro ilustre geógrafo norte-americano - Carl Orwin Sauer- na atual emersão de sua Geografia Cultural, que nunca medrara entre nós. Desejo tão somente focalizar sua contribuição teórica, no geographical cycle, como fio condutor num panorama evolutivo da Geografia ao longo deste século. Embora não haja dúvidas sobre que a proposta teórica de Davis seja um dos pontos de 
partida da Geomorfologia, prefiro conjugá-la ao contexto geográfico geral. Para mim, pessoalmente, é difícil (e até mesmo penoso) restringir-me a visões muito setoriais ou estanquemente compartimentadas na evolução do pensamento geográfico. Fruto de minha crença na unidade da Geografia, admito que esta atitude possa ser fruto de uma arcaica disposição romântica que remonte, talvez, àquela visão cosmológica, vinculada ao Zeitgeist, do nascedouro da Geografia como ciência.

Aliás, só agora, ao preparar esta palestra, deime conta de que nossa colega Lílian Coltrinari (1995), em muito boa hora, já promovera esta retomada da contribuição de Davis, ao lado de De Martonne, numa das Seleções de Textos da AGB. Alegra-me, pois, não estar só nesta missão de relembrar contribuições passadas, mesmo quando as novidades e propostas emergentes são tão copiosas, como estas vividas em nosso presente.

Nossa presente conversa constará de três momentos. Em primeiro lugar, pretendo focalizar a proposta teórica de Davis - do finalzinho do Século XIX - subestimada ou mesmo esquecida na convulsão da dita revolução teorética. A seguir, procurarei promover - embora muito rápida e sucintamente - um jogo de correlações sincrônicas, entre a Geomorfologia e alguns outros setores geográficos, ao longo do século vinte. Finalmente, procurarei - numa avaliação muito pessoal - expor algumas impressões sobre as tendências atuais de nossa Geografia, pelo que me tem sido dado notar de minhas últimas participações em fóruns geográficos nacionais.

\section{O CICLO GEOGRÁfiCO de W. M. DAVIS (Imaginação Criadora e Verdade Científica)}

Para minha geração ainda não está distante a eclosão da chamada Revolução Teorética na Geografia do final dos anos sessenta e ao longo dos setenta. Um dos pilares epistemológicos desta revolução foi o artigo de Fred Schaefer intitulado Exceptionalism in Geographya Methodological Examination publicado nos Annals of the Association of American Geographers, Vol. 43, n.3, September, 1953 pp.226/249. Um artigo póstumo, desde que seu autor falecera a 6 de junho do mesmo ano. Peça altamente polêmica abalava a estrutura epistemológica da Geografia, de Kant a Hartschorne. Mas, como tal, cheia de aspectos positivos e negativos. De qualquer modo, e antes de tudo, é um documento que reflete, muito claramente, a ênfase no caráter social na Geografia e, melhor do que isso, marca o advento do determinismo econômico sobre aquele ambiental. Estes são fatos capitais naquele artigo, que afloram após a insistência inicial no apelo à necessidade de leis gerais, como caráter essencial à ciência; na procura de universalidades em vez de excepcionalismos.
Science, to repeat once more, searches for laws. What then, one may ask, are the peculiarities of the laws we look for and which would make it advisable that they be kept together in one discipline? From this viewpoint, we believe that laws of geography fall into three categories. Typical of the first are most of the laws of physical geography. These are not strictly geographical. Many of them are specializations of laws independently established in the physical sciences. These we take as we find them, apply them systematically to the various conditions that prevail on the surface of the earth and analyze them with particular attention to the spatial variables they contain. To be specific, the climatologist uses much physics (meteorology), the agricultural geographer, applied biology (agronomy).

Para o tipo de Climatologia que vigorava naquela época (e até hoje, em certos centros), onde as vinculações com a Meteorologia eram fortes a ponto de legitimar como geográfica apenas a legalização estatística dos estados médios poderíamos compreender a argumentação de Schaefer. Para a Geografia Agrária (ou agrícola) ela causa mais surpresa porquanto ao lado dos sistemas agrícolas, onde se poderia imputar a aplicação agronômica, haveria que admitir aquela postura de ordenar, classificatóriamente, como numa competição esportiva, produto por produto. Mas talvez o autor incluísse esta linha no campo da Geografia Econômica que, em sua concepção, era a mais geograficamente legítima.

Typical of the second category are many laws of economic geography, for instance, the now flourishing theory - for it hás, indeed, reached the stage where one can speak of a theory in the strict sense of a whole group of deductively connected generalizations - of general location. As everybody knows, this theory investigates the spatial relations obtaining between the places at which the various economic factors, raw materials, producing units, means of communication, consumers, and so on, are to be found in any region. As far as they are morphological, these laws are genuinely geographic The pioneer work in this area has, in fact, been done by economists, if we except Cristaller, who is a geographer.

É muito difícil compreender esta legitimidade dos fatos econômicos onde a multiplicidade de fatores asseguram espacialidade. Fatos geomorfológicos, 
climáticos e agrários não admitem múltiplos fatores? Acompanhemos o raciocínio de Schaefer:

Geography is essentialy morphological. Pure geographical laws contains no reference to time and change. This is not to deny that the spatial structures we explore, are, like all structures anywhere, the result of processes. But the geographer, for most part, deals with them as he find them, ready made (As far as physical geography is concerned, the long term processes that produce them are part of the subject matter of geology). Let us in this connection consider Koeppen's Hipothetical Continent. The word hypothetical merely indicates that he neglected, for the purpose of his climatological generalization, all but a few variables. For the remaining ones he states a spatial correlation that is a morphological law. To call such comparatively crude correlation patterns, in this sense of patterns, are different from laws, would be a mistake. This absence of the time factor within physical geography is the source of a peculiar phenomenon within all branches of human geography (Op.cit, pp.244/244).

No seu afã de exaltar o nomotético sobre o idiográfico, além do mérito apontado para o continente hipotético de Koeppen (1917), o autor chega a absolver os ultra deterministas Helen Semple (1897) e Ellsworth Huntington (1945):

Geographical determinism or environmentalism attributes to the geographical variables the same role in the social process as Marxism does to the economic ones. This is no good reason to believe that either of these two special determinisms is anything but a gross exaggeration of some admittedly valuable insights. There is nothing wrong with investigating the influence which the physical environment exercises, positively or as a limiting condition, on the social process. Most geographers would expect to find lawful connections in this area; that does not make them geographical determinists. Ratzel was the first to think originally and imaginatively along these lines. Like Marx, he was not quite as bad as some of his latter days disciples. In this country Semple was a student of Ratzel. In Ellsworth Huntington's writings geographical determinism reaches some of its dizziest hights. In France Demolins insisted that in French history had to happen all over again it would essentially run the same course on account of the natural environ- ment. The contemporary reaction against these exaggerations is understandable strong. But to fight them from the standpoint of science is one thing; to fight geographical determinism in order to fight science and its underlying idea of universal lawfulness is another thing (op.cit., pp.247).

O que é mais surpreendente na abordagem de Schaefer é que ele ignora completamente a contribuição de W. M. Davis em sua proposta de Geographical Cycle, sobretudo quando se tem sob os olhos as três primeiras linhas de seu famoso artigo:

All the varied forms of the lands are dependent on - or, as the mathematician would say, are functions of - three variable quantities, which may be called structure, process and time.

Em sua proposta eminentemente teórica Davis evoca, para fins de legitimação, a linguagem matemática, requisito básico da ciência.. $\mathrm{O}$ artigo em pauta data do final do século XIX, intitulado The Geographical Cycle e publicado no Geographical Journal da Royal Geographical Society, em seu número 14, ano de 1899, entre as páginas 481 e 504. Nele, além de perseguir propósitos genéticos (causais) e não apenas topográficos (formais), enfatizando o caráter teórico, é feita, propositadamente, abstração de toda a gama complexa de vetores implicados no modelado terrestre. Partindo da classificação genética das formas, nos capítulos seguintes trata do papel do tempo como elemento da terminologia geográfica e a descrição do ciclo geográfico ideal.

Após a contribuição do engenheiro Surell (1841) formulando as leis da erosão fluvial, a partir do estudo das torrentes alpinas, de onde emergiram os primeiros conceitos fundamentais da Geomorfologia, a proposta de Davis vem dar um passo decisivo à sistematização do estudo do relevo terrestre. Uns ligeiros dados biográficos são necessários ao entendimento da contribuição deste geógrafo norte-americano.

William Morris Davis nasceu a 12 de fevereiro de 1850, na Filadélfia, Pensilvânia, na comunidade Quaker e estudou na Universidade de Harvard, onde foi professor de1876 a 1912. Desde 1870 dedicou-se ao estudo das formas de relevo terrestre. Sua formação em Geologia deu-lhe um forte fundamento, numa evolução que o dirigiu à Geografia Física, enriquecida também por sólidos conhecimentos de Meteorologia. Sua obra publicada inclui 42 itens de Meteorologia, inclusive um manual - Elementary Meteorology - editada em 1894. Chegou mesmo a dirigir, durante algum tempo, o Observatório Meteorológico de Mendoza, na vizinha Argentina. Publicou uma Physical Geography, em 1889 e a coletânea 
Geographical Essays, em 1909. Outras contribuições suas são: The Rivers and Valleys of Pennsilvania (1889); The Coral Reef Problem (1928); The Origin of Limestone Caverns (1931). Sua obra repercutiu fortemente na Alemanha, no inicio deste século, conforme atesta a edição da obra Die erklarende Deschribung der Landformen (1912). Faleceu em 5 de fevereiro de 1934, tendo vivido 84 anos.

Emmanuel de Martonne (1909-1925), no seu Traité de Géographie Physique - Tome 2 - Le Relief du Sol, ao apreciar o historique do estudo das formas do relevo terrestre (Chap.II - Séc.13), após registrar os precursores, registra que:

C'est dans les dernières années du XIX ème siècle qu'a été accompli l'éffort le plus vigoureux pour systématiser les idées sur l'évolution des formes des terrains. Il a été l'oeuvre d'um esprit um peu abstrait, constructeur plutot qu'observateur; dans une série de mémoires publiées de 1889 a 1900, W. M. Davis a precisé toutes les notions essentielles, crée des mots qui ont fait fortune: pénéplaine, cycle d'érosion, forgé une nomenclature pour les accidents em rapport avec la structure; il a contribué puissament à donner l'apparence d'um corps de doctrine aux idées dégagées par differents observateurs. Ellargissant peu à peu le champ de son activité, il a essayer de faire le même travail pour les familles de formes outres que celles d'érosion normale, mais, semble-t-il, avec moins de succès (De Martonne, op.cit.p.546).

Notemos, preliminarmente, a observação adjetiva conferida pelo francês ao norte-americano: espírito um pouco abstrato, mais construtor que observador, o que assenta aos propósitos teorizantes do segundo. Em seguida notemos o uso do termo erosão normal, originalmente usada como erosão ideal (pelo menos naquele artigo de 1899).

Note-se, também, que o rótulo do clássico ensaio de Davis é Geographical Cycle (Ciclo Geográfico) e não ciclo de erosão como seria, posteriormente, consagrado. Ao procurar montar o modelo genético da evolução das formas de relevo, base de todo o cenário que caracteriza a crosta terrestre e constitui o embasamento da atuação do Homem, Davis desejou - intui-se claramente - acrescentar o geográfico ao geológico. O conceito de ciclo geológico já era aquisição estabelecida nas Ciências da Terra, composto de suas fases: litogênese (geração das rochas); orogênese (deformação das estruturas rochosas pela força dos agentes internos) e gliptogênese (modelado erosivo, esculturador de formas pelos agentes externos). Esta última era, assim, emi- nentemente geográfica. Como cada ciclo geológico só tem início por uma nova litogênese, fica claro que um ciclo geológico pode admitir alternadas fases de orogênese e gliptogênese; o ciclo geográfico se iniciaria, assim, por uma superfície - litogenética primária ou de aplainamento gliptogenético ou erosivo. Ao abstrair - por simples estratégia didática - a intervenção real e efetiva (jamais negada) dos múltiplos fatores morfogenéticos, sempre foi deixado claro a possibilidade das peneplanícies (de senilidade) admitirem a existência de relevos residuais, assim como que, a sucessão das diferentes fases vitalistas (juventude, maturidade e senilidade) poderia ser interrompida, gerando relevos policíclicos capazes de assumir alta complexidade. Um eloqüente exemplo disto emergiu dos estudos daviseanos do complicado relevo dos Apalaches (ou Aleghanis).

Estas considerações remetem-me de volta aos idos de 1952-53, quando estudante na Faculté des Sciences de l'Université de Paris (Sorbonne), quando cursei e obtive o Certificat d'Etudes Supérieures em Geographie Phisique et Geologie Dynamique. A disciplina de Geologia (ao lado de MineralogiaPetrografia, Oceanografia e Climatologia), naquele ano letivo, foi ministrada pelo eminente geólogo Leon Lutaud, em seu último ano de docência, já atingida a compulsória. Aquele notável geólogo francês, especialista nas famosas écailles provençales, em suas aulas, enfatizava muito bem as relações entre os ciclos geológico e geográfico, proposto por Davis, além de uma alentada análise sobre a contribuição de Surrell, em suas leis da erosão fluvial (novidade para mim) de onde provieram os conceitos básicos de nível de base, erosão regressiva, perfil de equilíbrio, gênese das capturas etc., etc.

Ainda, a propósito de abstração e construção teórica na proposta daviseana, é preciso lembrar que, na virada dos séculos XIX para XX projetava-se muito a filosofia de Henry Bergson, com suas concepções originais sobre o tempo espesso e exaltação da imaginação criadora. Davis, nas ciências da Terra, reflete aquilo que Marcel Proust realizou na literatura. E isto será lembrado e criticado, mais tarde, no meio do século, sobretudo na acerbada crítica feita a Davis por Jean Tricart, como veremos adiante.

Consciente de suas abstrações teóricas, em sua proposta cíclica, e ante a variedade climática fonte da ação gliptogenética - no globo terrestre, Davis referia-se, no seu modelo, a uma (abstrata) erosão ideal ou seja, aquela ligada às regiões temperadas das latitudes médias do hemisfério norte, com vigência das quatro estações e pluviosidade farta mas moderada, emoldurada por climas mediterrâneos e árticos. Assim é que, imediatamente após este núcleo climático ideal ele vê-se forçado a focalizar os casos contrastantes das condições glaciares e áridas (glacial denudation e arid climates). 
O que foi tomado como ideal na proposta daviseana, foi desviada para normal, à medida que se difundia sua obra, entre outros estudiosos das formas de relevo, inclusive De Martonne. Uma curiosíssima normalidade quando refletimos que aqueles condicionamentos climáticos vigoram apenas em cerca de $10 \%$ da superfície do globo terrestre. Eis aqui um eloqüente exemplo de visão do Mundo eurocentrista, ocidental, onde o normal, desvinculado de qualquer ordem de grandeza, reflete a pretensão dos centros hegemônicos da economia e poder político mundial em considerar como normal aquilo que lhes é peculiar. Assim é que, embora flagrantemente dominante, em seu conjunto, e mesmo superior setorialmente, a maioria da superfície terrestre é considerada como acidental.

De Martonne principia o seu capítulo (III do Tomo 2) relativo ao Modelé d'Érosion Normale pelos conceitos básicos obtidos no estudo das torrentes alpinas por Surell (1841) e sua concepção de modelado normal é bem explicitado:

Il est certain que nous sommes loin d'être aussi avancés dans la connaissance des familles de formes glaciaires et désertiques que dans celles des formes d'érosion qu'on observe dans les pays où se concentrent les societés humaines. Tout nous engage à commencer par celles-ci et a y insister particulièrement (De Martonne, op. Cit. p.547).

Assim, no domínio das acidentalidades ou excepcionalidades, o modelado das amplas regiões intertropicais úmidas é descartado. No início do século, o colonialismo europeu - que substituíra o ibérico - contentava-se em sugar daquelas regiões exóticas e de culturas diferentes (e inferiores) os seus recursos naturais para alimentar seu crescimento industrial e poderio político. Tudo ou quase tudo que ocorria além da linha dos trópicos, inclusive flutuações climáticas quaternárias, não sintonizava com o mundo normal.

Retenhamos, por enquanto, neste final de nossa primeira etapa, que a contribuição de W. M. Davis, trazida do finalzinho do século passado, foi decisiva na sistematização dos estudos geomorfológios, e atravessará toda a primeira metade do século XX, com naturais acréscimos, ampliações e deformações, em outras escolas geográficas, para, atingida o meio do século, sofrer fortes impactos críticos à sua metodologia, enquanto, a ampliação dos conhecimentos e do arsenal técnico de análise virão trazer novos impulsos não só à Geomorfologia mas à Geografia em geral.

\section{RETROFLEXO EVOLUTIVO DA GEOGRA- FIA NO SECULO XX (A Geomorfologia nesse contexto )}

Para tentar, no âmbito de nossa conversa, focalizar um panorama evolutivo da Geomorfologia, após o legado de Davis - dentro do contexto da evolução da Geografia no Século XX - e associar esta evolução em sintonia com os grandes acontecimentos científicos, políticos e culturais, procurei esboçar um quadro auxiliar. Nele, o desenvolvimento linear, diacrônico - em barras paralelas - visa articular, simultaneamente, as correlações sincrônicas entre eles. Note-se que, se quisesse privilegiar o presente ou os tempos mais próximos, poderia ter recorrido a uma escala logarítmica (ou quadrática) pela qual os anos mais recentes se beneficiariam de um espaço maior, capaz de comportar maior número de registros. Contudo, em sintonia com minha atual situação - mais passada do que presente - isto foi descartado. Veja-se, no plano mais inferior do quadro, o posicionamento do observador - este que vos fala - nascido em 1927, licenciado em 1950 (no exato meio do século) e exercida sua militância universitária entre 1955 e 1990. Assim, o início do século é objeto de pesquisa; o meio de atuação vivida; o final, de contatos indiretos e observação com um certo afastamento.

$\mathrm{Na}$ parte superior do referido quadro estão dispostas as barras relativas aos magnos acontecimentos mundiais na política, filosofia, artes, ciênciatecnologia, cultura de um modo geral. Na parte central desenvolvem-se as barras relativas ao Brasil, em seus marcos político-sociais e Geografia, mesclandose nesta barra eventos mundiais e nacionais. Na parte inferior encontra-se a barra da Geomorforlogia, avizinhada àquela da Climatologia, não apenas pelas afinidades de Geografia Física mas, sobretudo, por se tratar de minha área de mais efetiva atuação e, como tal, mais propícia às possíveis correlações teóricas. Deve ficar bem claro que a montagem do quadro obedece a um viés muito pessoal, segundo as limitações do conhecimento do autor. Qualquer colega sentirá falta ou poderá discordar quanto a seleção de eventos aí figurados. Eu próprio considero que, para melhor caracterização geomorfológica, seria da maior utilidade acrescentar barras relativas à Pedologia e a Geologia, pelo menos na interface do quaternarismo. Contudo, falta-me o necessário conhecimento para, com a devida segurança, registrar os eventos capitais nestes dois campos de conhecimento. Mas o esquema é completamente aberto a todos os possíveis acréscimos e correções.

A passagem dos séculos XIX ao XX foi marcada por uma esplêndida pirotecnia na Filosofia, nas Artes e na Ciência. Nietzsche, que concluirá sua obra em 1888, e faleceu em 1900, promovera um desmonte em arraigadas concepções, sendo o grande 
Monteiro, C. A. de F. / Revista de Geomorfologia, volume 2, nº 1 (2001) 1-20

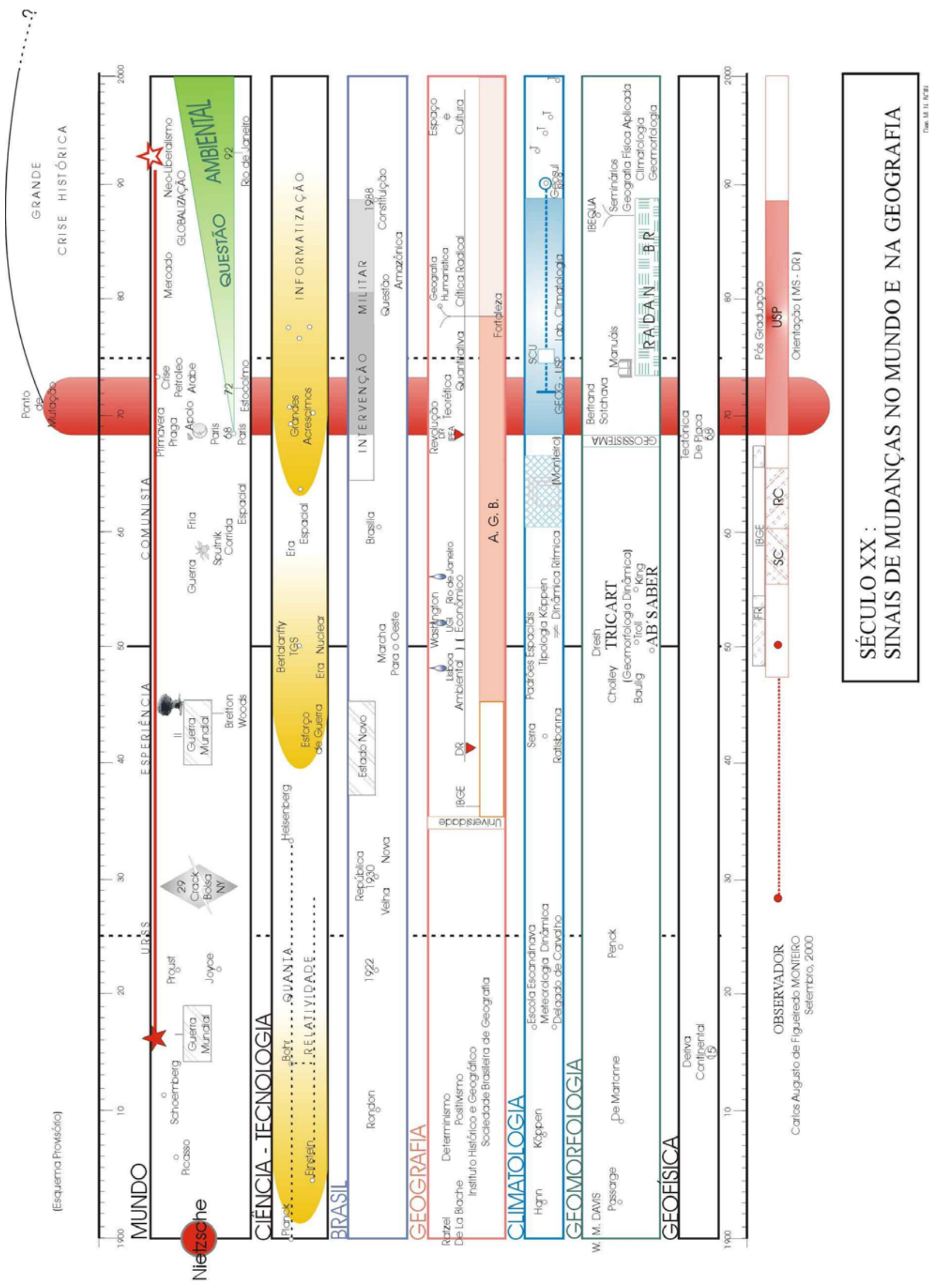


portador de novas luzes necessárias à evolução do novo século. A Ciência era abalada tanto no nível do macro-físico - com Einstein (1879-1955) e a Teoria da Relatividade - quanto naquele do micro-físico - com Max Planck (1858-1947) com a Teoria dos Quanta. A proclamação de Plank dos valores discretos ou quanta reveladas num oscilador de partículas é de 14 de dezembro de 1900. Os cinco artigos que fundamentaram a Relatividade de Einstein foram capitais, publicados em 1905. Picasso, ao estampar u' a máscara africana no rosto de uma das Demoiselles d'Avignó, em 1907, cria o cubismo. Schoenberg revoluciona a harmonia musical, com o dodecafonismo, no seu Harmonielehre, em 1912. Por esta época o Ballet Russo conquista Paris. As Ciências Naturais progridem enquanto as Humanas tomam corpo. As velhas concepções de Economia Política, dos séculos precedentes, são prolongadas pelo novo século a dentro enquanto os progressos do capitalismo geram mecanismos financeiros ainda desconhecidos que culminam com o crack da Bolsa de Nova Iorque, em outubro de 1929, inaugurando uma grave recessão mundial.

Diz-se que o século XX principiou atrasado, inaugurando-se após a primeira grande guerra mundial, no decorrer da qual, em 1917, deu-se a revolução bolchevique russa. Neste último sentido, pode-se admitir que se findou adiantadamente, com o desmonte da URSS. De qualquer modo, esta experiência política, fruto do marxismo, abrangeu três quartos deste século, sendo um dos seus marcos. $\mathrm{Na}$ segunda década, enquanto o Brasil celebrava seu centenário de independência e tentava assumir um caráter nacional nas artes (Semana de Arte Moderna em São Paulo), em 1922, neste mesmo ano, eram editados dois pilares na literatura do novo século com o Ullyses de James Joyce e o A la récherche du Temps Perdu de Marcel Proust.

A Geografia Ciência, do seu nascedouro alemão, ingressa no novo século oscilando na querela determinismo (Ratzel) - possibilismo (de la Blache) enquanto se geram as escolas nacionais européias e norte-americanas, mediante a institucionalização da disciplina nos currículos universitários. Os estudos de Geografia Física fornecem as bases aos estudos regionais, onde a ação do Homem é apreciada em suas relações com a natureza. $\mathrm{O}$ estudo dos gêneros de vida nos grandes biócoros guarda muito de ilustração etnográfica na emergente Antropologia. Após o legado de Surell e Davis, a Geomorfologia continua a evoluir preocupada em distinguir da erosão normal aquelas das regiões áridas (Passarge, 1904) e glaciais de montanha (Penck,1924). Mais adiante, Cotton (1942) tenta completar o quadro dos Climatic Accidents in Landscape Making. $\mathrm{O}$ estudo dos climas repousa nas bases traçadas pelo austríaco Julius Hann (1903) com definição caracterizada pela abstração dos estados médios da atmosfera sobre os lugares. Ao final da guerra, W. Köppen (1917) propõe o seu sistema de classificação, segundo a concepção estatística de Hann, ilustrada por seu continente hipotético louvado como tentativa de universal científica por Schaeffer.

No Brasil, as primeiras décadas do século são uma extensão dos tratamentos corográficos de uma geografia descritiva, do século anterior, ligada aos Institutos Históricos e Geográficos, federais e estaduais, e da Sociedade Brasileira de Geografia. Os compêndios didáticos bafejados pelo aval do Colégio D. Pedro II, do Rio de Janeiro, norteavam o ensino da disciplina no ensino médio. Em 1917, ocorre a surpreendente edição (em Paris) de uma Météorologie du Brésil, de autoria de Delgado de Carvalho. Surpreendente pela escassez dos dados disponíveis, bem como pelo próprio tratamento dado pelo autor, foi merecedor de um elogioso prefácio do meteorologista inglês, Sir Napier Shaw. A seguir, Delgado de Carvalho, associado ao engenheiro Henrique Morize, lançaria a primeira classificação climática do território brasileiro. A procura de recursos minerais que, desde a segunda metade do século anterior ensejara a vinda de geólogos europeus e norte-americanos para o Brasil, continua a produzir os estudos pioneiros sobre o embasamento geológico e formas de relevo.

Após a Revolução de 1930, inaugurada a dita República Nova, com a implantação das universidades no Rio de Janeiro e em São Paulo (1934) é que se inicia a institucionalização da disciplina - associada à História - nos cursos superiores, implementada com a colaboração de docentes franceses. Um outro marco na evolução dos estudos geográficos entre nós, advém da fundação da Associação dos Geógrafos Brasileiros, orientada por Pierre Deffontaines (1935). Congraçando, de modo aberto, cientistas dos setores afins, geólogos, historiadores, engenheiros etc., a primeira década foi incipiente, sendo revigorada após uma revisão nos estatutos, em 1945, a partir do que se tornou altamente dinâmica, promovendo assembléias anuais em diferentes regiões brasileiras, irradiando entusiasmo para a pesquisa geográfica. A ditadura Vargas - rotulada de Estado Novo, no mesmo ano de sua implantação (1937), criava o Instituto Brasileiro de Geografia e Estatística (IBGE), promovendo pesquisa geográfica e publicações especializadas (Revista Brasileira de Geografia e Boletim Geográfico). Os três Conselhos, em que se subdividia o IBGE: Geografia, Cartografia e Estatística, num organismo diretamente vinculado à Presidência da República, demonstrava a importância que o poder público conferia à pesquisa geográfica, a produção cartográfica (compartilhada com aquela produzida pelas forças armadas), os levantamentos estatísticos rotineiros e a realização de censos decenais, como elementos indispensáveis à administração 
pública. Enquanto as Universidades preparavam, concomitantemente, professores (licenciados) para o ensino médio e superior, e pesquisadores (bacharéis), estes últimos, além de destinados às próprias Universidades, podiam abastecer os quadros técnicos do Conselho Nacional de Geografia. Uma das atribuições deste órgão era a elaboração da Divisão Regional do Brasil, prática norteadora da administração pública. A primeira divisão regional, produzida para nortear o recenseamento de 1940, foi publicada no ano seguinte (Guimarães, 1941).

A Geografia da primeira metade do século $\mathrm{XX}$ foi marcada por uma forte preocupação com as componentes naturais, onde os estudos geomorfológicos forneciam as bases para as abordagens regionais. De Martonne, além do seu tratado de Geografia Física, produziu um primoroso estudo regional sobre La Valachie. Aliás, uma das tradições na escola francesa de Geografia, à qual estivemos fortemente ligados, era a ênfase da Geografia Física na formação de seus geógrafos, fato que se pode constatar até na terceira geração, onde geógrafos que se notabilizariam na área de Humana, produziram estudos relevantes em Geomorfologia, como os casos de Pierre George ( $L a$ Plaine du Bas Rhône) e Mmme. Beaujeau-Garnier (Le Morvan).

Uma das características que pode ser apontada para esta fase é a produção de uma análise geomorfológica acompanhada de excelente ilustração cartográfica. Os principais geomorfólogos, a principiar pelo próprio Davis, eram excelentes desenhistas que expressavam suas idéias evolutivas do modelado terrestre à base de bem executados blocos diagramas. De Davis, passando por De Martonne, até atingir sua culminância no norte-americano Lobeck (1939), cujo manual de Geomorfologia era muito rico, tanto em fotografias como em desenhos. A ele se deve, também, um manual de desenho cartográfico onde se encontra (ainda hoje) a melhor explicação para construir blocos diagramas (1924-1958).

Outra característica desta fase daviseana era aquela de que, malgrado a evolução do modelado basear-se em pré-supostos abstratos, quando se atingia o entendimento da realidade do relevo terrestre ela era sempre conectada ao povoamento, às formas de ocupação do solo, aspectos econômicos, enfim à fenomenologia humana. Neste sentido relembro o capítulo da Geomorfologia de Lobeck, relativa aos relevos associados às estruturas em domos, onde a disposição dos arcos concêntricos, de formas monoclinais (cuestas e hog-backs), eram associadas ao povoamento e a advertência de que a desnudação do núcleo intrusivo propiciava, o mais das vezes, uma paisagem mineradora. $\mathrm{O}$ tratamento dos relevos de cuestas na França, nos arcos concêntricos da Bacia Parisiense, explicava não só mas propiciavam boas condições de solos e de exposição solar à cultura da vinha, como também o seu significado estratégico. Lembrando a descoberta de Yves la Coste de que a Geografia é algo que sert à faire la guerre as formas de relevo da bacia parisiense inspiraram a estratégia (fracassada) da Linha Maginot.

$\mathrm{O}$ fato de que a primeira metade do século XX é o nascedouro da Geografia-Ciência entre nós no Brasil, sintoniza perfeitamente com o estágio histórico de nossa própria formação social. Na primeira década, o povoamento ainda restringia-se, significativamente, à faixa litorânea. Lembremo-nos da odisséia da missão Rondon quando, no auge (já início do declínio) do boom da borracha na Amazônia, se instalavam as linhas telegráficas para Manaus. Nos anos trinta surgem obras capitais no nosso auto-conhecimento como Casa Grande e Senzala (1933) e Sobrados e Mucambos de Gilberto Freyre (1936) mais Raízes do Brasil de Sergio Buarque de Holanda (1936) e Formação do Brasil Contemporâneo de Caio Prado Junior (1942). A segunda grande guerra e o esforço para a industrialização, nos anos quarenta, nosso esforço na Marcha para o Oeste, conjugando o esforço terrestre da Misssão Roncador-Xingu dos Irmãos Villas Boas, com os aéreos da FAB. A necessidade de tomar posse para conhecer o território e refletir sobre nossa formação sócio-econômica eram necessidades imperiosas para o que a contribuição geográfica, conjugada pela ação conjunta das universidades pioneiras, IBGE e AGB deram importante contribuição. $\mathrm{O}$ desenvolvimento tecnológico produzido pelo esforço de guerra trouxera o precioso auxílio da aerofotogrametria. $\mathrm{O}$ antigo e complicado sistema trimetrogon de fotos inclinadas, foi enriquecido por tomadas verticais, o que contribuiu muito para os estudos geomorfológicos entre nós.

Nossos estudos geomorfológicos radiaram dos dois centros universitários básicos. No Rio de Janeiro houve a contribuição inestimável do mestre francês Francis Ruellan, discípulo de De Martonne, atuando concomitantemente na Universidade do Brasil e no Conselho Nacional de Geografia, formador das equipes iniciais. Na Universidade de São Paulo - onde a atuação dos mestres franceses, notadamente Pierre Monbeig, estava mais voltada para a Geografia Humana - as bases geomorfológicas foram autóctones. Iniciada pelo geólogo Luiz Flores de Morais Rego (1943), que delineou as bases da interpretação das formas do relevo do território paulista, elas se continuaram por obra de notáveis geólogos, dentre os quais salientaríamos Otavio Barbosa e Fernando Flávio Marques de Almeida os quais, dentre outros méritos tiveram aquele de haverem dito ativíssimos participantes da obra da Associação dos Geógrafos Brasileiros, em sua melhor fase Juntou-se a estes, antes mesmo de concluir o curso, o geógrafo Aziz Nacib Ab'Saber que, beneficiado por uma excelente formação em conhecimentos geológicos, destacou-se 
muito cedo no setor da Geomorfologia. Enquanto isto o quadro da Geografia Física, no Brasil, completava-se por estudos climatológicos ainda limitados pela insuficiência de informação meteorológica e restrita à aplicação da classificação do Köppen em estudos locais e regionais. A Biogeografia, despontava, a partir de um curso ministrado no Conselho Nacional de Geografia do IBGE, no Rio de Janeiro, pelo canadense Dansereau, cujo conteúdo ensejou a publicação de um notável artigo na Revista Brasileira de Geografia (1949).

Mas será de toda justiça assinalar que antes de atingir o meio do século, a Geografia produzida no Brasil, em ativas assembléias e publicações periódicas, já era capaz de exibir contribuições de destaque. Lembremo-nos de que, para restringirmo-nos ao setor da Geografia Física, desde 1941, com a publicação do artigo Ondas de Frio na Bacia Amazônica, os meteorologistas Adalberto Serra e Leandro Ratisbona, praticantes de uma meteorologia dinâmica, advinda da escola escandinava, lançavam os alicerces para o futuro nascimento de uma climatologia mais geográfica. Aziz Ab'Saber já produzira o seu notável trabalho sobre os fenômenos de desnudação pós-cretácea (1949). Como expressão de uma Geografia globalmente integrada, Hilgard O'Reilly Sternberg publicara, na RBG, um primoroso estudo sobre uma calamidade pluvial na Bacia do rio Paraíba do Sul, no qual desnudara a trama de todo um jogo de relações integradas entre a herança da cultura cafeeira transformada em pastagem, criando condições extremamente vulneráveis ao desencadeamento de movimentos coletivos do solo. Este estudo foi o pioneiro numa linha de pesquisa de destaque na realidade do Brasil tropical atlântico.

Outro rumo trazido pela guerra, com a destruição dos espaços urbano-industriais na Europa, foi a necessidade de, para reconstruí-los, planejá-los. Assim, a Geografia viu-se lançada a um comprometimento com o planejamento territorial, passando-se a discutir, para ela, a adequação adjetiva de aplicada ou aplicável. Tendo sido sempre temática geográfica, os estudos urbanos passaram a se revestir de maior relevância, ampliadas, sobremodo, pela importância que se passou a dar à Economia. Antes de findar a guerra, em Bretton-Woods (1944), consoante a nova configuração do poder mundial, o Reino Unido passava o bastão da liderança econômica aos Estados Unidos enquanto, naquele mesmo tratado eram criados o Banco Mundial e o Fundo Monetário Internacional (FMI). Já atingimos o meio do século, no momento mesmo em que eu concluía a Universidade e passava a integrar-me, mais efetivamente, na prática geográfica. No momento em que me encaminhava para a pesquisa geográfica mais voltada para a natureza, dava-se a grande mutação que foi o advento do determinismo econômico em substituição àquele dito ambiental. Em termos globais, aponta-se a Urban Geography de Griffith Taylor
(1949) como sendo o último suspiro do determinismo ambiental.

Nada melhor para retratar esta passagem do que confrontar os três congressos internacionais, promovidos pela União Geográfica Internacional (UGI), no meado do século. Naquele de Lisboa (1948) foi retomada a realização sistemática daqueles eventos, realizados de quatro em quatro anos, prática interrompida na vigência da guerra. Ali ainda houve preocupação para ensejar a criação da Comissão para o Estudo das Superfícies de Aplainamento em torno do Atlântico, tema que aliava de um lado, a preocupação daviseana com as grandes superfícies aplainadas; do outro, ao vinculá-las em torno do Atlântico notava-se a relação à teoria da Derivação Continental (Pretérita união da América do Sul com a África, no Continente de Gondwana) proposta por Wegener em 1915. Quando aluno de Jacques Bourcart, na disciplina Oceanografia, na Faculté des Sciences, da Sorbonne, no ano letivo de 1952/53, os estudos sobre a margem continental daquele mestre promoviam alentada revisão crítica naquela teoria, mostrando tanto pontos de concordância quanto evidências de discordâncias. $\mathrm{O}$ congresso de Washington (1952), pelo temário e comissões, revela o peso dado à Economia. Esta passa a varrer todos os campos de preocupação acadêmica e profissional. Tenho repetido o fato da pomposa declaração do famoso arquiteto Mies van der Hohe, ao concluir seu edifício das torres de aço e vidro de Chicago (1951) de que o projeto arquitetônico é a economia. Toda a esfera dos conhecimentos passa a girar sob o impulso dos processos econômicos, conduzidos pelo antagonismo capitalismo-comunismo, ao sabor da guerra fria. Lembro-me da reação do velho mestre inglês, o geomorfólogo Wooldridge, em sua obra The Geographer as Scientist, onde se refere ao fato de verse a superfície terrestre como simples palco para o desenrolar da atividade econômica como uma idéia narrow and nasty (estreita e tola). O memorável congresso do Rio de Janeiro (1956) vai registrar uma outra importante mudança: aquela do dinamismo que passa a caracterizar o estudo dos processos na Geomorfologia. Na França, a Revue de Géomorphologie Dynamique, surgida no final dos anos quarenta, já vinha se desencumbindo de promover grande impulso nessa abordagem do modelado terrestre.

A Geomorfologia na França, após a geração De Martonne (Paris), Blanchard (Grénoble) dá lugar àquela de Cholley (Paris), Baulig (Strasbourg). Do primeiro deve-se a estratégia didática da abordagem tríplice na Geomorfologia: Estrutural, Climática e Litorânea. A terceira geração, aquela do pós-guerra é liderada por Tricart (Strasbourg) e Dresh (Paris). Ambos ampliaram os seus campos de estudo para o território africano: Dresh no árido da borda mediterrânea e Tricart no tropical úmido da então Afrique Noire. 
Outro enriquecimento científico do pósguerra foi a introdução da Teoria Geral dos Sistemas proposta pelo biólogo Von Bertalanffy (1950) em que iria ter grande repercussão mas que só chegaria para a Geografia, no Brasil, junto com a revolução teorética.

A progressão dos estudos geomorfológicos no semi-árido e sobretudo no intertropical africano, pouco a pouco, foram revelando sinais de que, as flutuações climáticas do quaternário haviam repercutido sim, muito além das latitudes médias. A observação de stone lines, paleopavimentos e caracteres pedológicos chamavam a atenção dos geomorfólogos. A estas observações climáticas, na África do Sul vieram juntar-se outras observações capitais, relacionadas à implicações tectônicas e isostáticas, feitas por Lester King (1955) na geração de pediplanações e seus resíduos (Inselgebirge). Neste meio de século, no Brasil, os núcleos basais de São Paulo e Rio de Janeiro já haviam sido acrescidos de outros. De modo autóctone no Paraná, pela atuação do geólogo alemão R. Maack, formando uma eficiente equipe, onde já emergia J. J. Bigarella: ou seja, conquistado pela obra difusoraintegradora da AGB, em Pernambuco, com Gilberto Osório de Andrade, Rachel Caldas Lins, Manoel Correa de Andrade (inicialmente geomorfólogo) e principiando na Bahia, com os primeiros bolsistas enviados à França, estas observações nos cortes reveladores da estrutura superficial da paisagem, já despertavam interesse. Ao ensejo do congresso da UGI houve o auspicioso encontro de geógrafos dos grandes centros e os nossos. Fosse nas sessões do congresso, mas especialmente nas excursões de campo em diferentes regiões brasileiras, por especialistas estrangeiros, notadamente os geomorfólogos Tricart e Dresh, houve oportunidade para um proveitoso diálogo com os nacionais. Assim é que, o congresso do Rio de Janeiro, de 1956, dentre muitos outros méritos, pode ser considerado como um marco na nossa Geomorfologia, que se enriqueceu desse renovador caráter dinâmico. A partir daí estreitaram-se os laços de colaboração e intercâmbio entre Brasil e França na Geomorfologia, notadamente com a atuação de Tricart junto a UFBa, com a criação do Laboratório de Geomorfologia e Estudos Regionais. Além do treinamento local de seus geógrafos, atraiu outros que para ali convergiram, de outras regiões. Também fomentava a troca de idéias, ajudada pelos encontros anuais nas assembléias da AGB.

O dinamismo e ênfase processual na geração das formas do relevo viria assentar-se sobre uma séria crítica à metodologia daviseana. E, neste particular, o porta voz mais ferrenho foi Jean Tricart. Embora concedendo a W. M. Davis o crédito de fundador da Geomorfologia como disciplina especializada, Tricart aponta como único mérito de Davis aquele de apresentar um conjunto coerente, um sistema. Mas ataca, radicalmente, os dois pilares sobre os quais ele se apo- iaria: a noção evolutiva cíclica e a concepção de erosão normal. Mas o cerne de toda a crítica é centrada no fato de que Davis coloca a intuição no lugar da observação, pecado advindo das concepções filosóficas de Bergson qu'a saisi le drapeau em lançant des concepts comme celui de l'immagination créatrice, é sobre este pedestal filosófico que principia a demolição, na maior veemência. Esta crítica principiada pessoalmente nos seus muitos cursos avulsos policopiados pela Presses Universitaire de France (PUF), avulsamente, acabou por ser ordenada em sua obra, intitulada Principes ot Méthodes de la Géomorphologie, da qual permito-me lembrar o seguinte trecho:

La méthode de Davis est significative. Ne $s$ 'est-t-il pas emporté, plein de mépris, contre ces gens qui manquent d'immagination? N'at-il pas affirmé que le recours systhematique et massif à l'immagination était la caractéristique méthodologique de la géomorphologie? N'em fit-il pas lui-même l'éclatante démonstration em se plaçant le dos au paysage et em imaginant comment celui-ci devait être, comment il s'était elaboré et, ensuite em se retournant pour découvrir, plein de vaniteuse satisfaction, qu'il était bien conforme à ce qu'il avait échafaudé? Autre anedocte significative: la campagne dans les Mers du Sud pour l'étude dês récif coraliens, pendant laquelle Davis, enferme dans as cabine, étudiait les cartes et reconstituait la genèse des récifs dont, ensuite, une courte escale et um rapide coup d' oeil étaient censés démontrer l'exactitude... Une telle aberration méthodologique a directement mené à une practique incroyable, que avait encore cours dans certaines universities tout récemment: celle de limiter les travaux practiques d'étudiants à la seule observation de la carte topographique. On regardait lê modelé et on en déduisait la nature des roches et les accidents structuraux, puis, ensuite, on rendait compte du modelé à partir des éléments soi-disant acquis de cette manière. Monstrueuse faute de méthode, qui n'a pu etre commise que par des personnes ignorant les plus élémentaires príncipes de la méthode scientifique. Toute loi scientifique se déduit d'une corrélation systhematiquement observée entre de nombreuses données d'ordre different, portées les unes sur l'axe des $x$, les outres sur l'axe des y. Le modele est une donnée, la structure em est une autre. Leur confrontation aboutit à l'établissement d'une corrélation. Mais on ne peut tirer $x$ et y de la même équation, seule et unique. En tentant de le faire, ou about-it nécessairement à une 
solution arbitraire que, dans notre cas, est une pétition de principe ou, si l'on préfère, une vulgaire devinette... On conçoit combine de semblables pratique on pu effarer les autres naturalists et la prevention qu'elles ont crée vis-à-vis de la géomorphologie.

Cette grave faute de méthode est sensible tout au long de l'oeuvre de Davis, mais devient de plus en plus apparente avec le temps: les exemples les plus outranciers correspondent à la seconde décennie de notre siècle. Mais l'insuffisance méthodologique est sousjacente aux concepts fondamentaux de la géomorphologie davisienne qui sont une construction de l'esprit pure et simple, certes douée de cohesion interne, mais qui ne repose pas sur une observation systématique des faits. En somme, la différence entre l'intrigue bien menée d'un roman de fiction et la réalité quotidienne (Op, Cit, pp. 63/64).

Contrapondo-se ao verbalismo imaginativo de Davis, Tricart examina les tatonnements des écoles germano-slaves, sobretudo destas últimas: Lomonosov, séc. XVIII; Kropotkine, segunda metade do século XIX e Dokoutchaev, pai da pedologia, no final daquele século. A falta de consideração da cobertura de solos e vegetação é uma das grandes demonstrações da abstração daviseana. E é nos alemães que o crítico francês vai encontrar o cerne da necessária fundamentação climatológica, reveladora dos efetivos processos.

A apaixonada crítica de Tricart, justa em muitos pontos, carece da compreensão do que a proposta de Davis continha de propósito didático. Didática também foi à preocupação de Cholley ao preconizar o tratamento separado das componentes estruturais das climáticas e completá-las pela azonalidade das bordas litorâneas. Qualquer um geógrafo a quem já tenha sido dada a tarefa de ensinar geomorfologia, sabe bem das dificuldades em explicar aos alunos tal complexidade e superposição de fatores contidos na geomorfogênese. Eu próprio usava a estratégia de, nas disciplinas finais, recorrer a uma abordagem regional específica para afastar todas as abstrações teóricas. E forneci, a este propósito, um depoimento, ao elaborar o ensaio Geossistemas - A Estória de uma Procura (Monteiro, 2000).

Em minha carreira acadêmica, sobretudo na função docente, aproveitei muito dos ensinamentos tanto de Davis quanto de Tricart. Concordei com este último quando ele enfatizou que la notion de cycle doit donc être remplacée par celle d'évolution, séquence. $\mathrm{E}$ foi exatamente por isso que procurei um paradigma mais satisfatório para a Climatologia que pratiquei. Se ele repousa basicamente na revisão crítica formulada por Sorre, como já expus exaustivamente, também considerei muito esta colocação de Tricart sobre a importância da seqüência no estudo dos processos. Daí minha preocupação em centralizar o estudo climático no ritmo, no estudo das seqüências de tipos de tempo, capazes de, embora muito difícil, aproximar-se daquilo que seria o habitual. Se era válido produzir uma Geomorfologia Dinâmica por que não o seria também perseguir uma Climatologia Dinâmica? E é em nome dessa associação - que a meu ver nivela logicamente e sincroniza modos de análise, em proveito da unidade da Geografia - que eu procurei incluir no quadro uma barra relativa à Climatologia, na qual, sem pretensão descabida ou falsa modéstia, registrei etapas importantes em minha contribuição aos estudos climatológicos em nosso país. No final dos anos cinqüenta e ao longo dos sessenta, encontrei o apoio na literatura meteorológica brasileira, notadamente em A. Serra, o apoio necessário para enfronhar-me nos mecanismos da circulação atmosférica na América do Sul. E fiz um grande esforço para, partindo do material precário disponível naquele então, em cartas sinóticas rudimentares, anteriores ao benefício das imagens do satélites, compreender os mecanismos daquela circulação. Ao procurar iniciar os meus alunos universitários naquela prática de análise, defrontei-me com uma grande dificuldade didática. Foi quando ocorreume recorrer a estratégia daviseana de imaginar um ciclo que, embora abstrato, servisse à iniciação dos meus alunos numa tarefa difícil. Ao tratar do Clima da Região Sul da Geografia Regional do Brasil, editada pelo IBGE em 1963, inseri o esquema Ciclo Vital de uma Onda de Frio que, abstraindo as costumeiras complicações de que se revestem os avanços de Frente Polar Atlântica sul-americana, exibia quatro estágios: prenúncio, avanço, domínio e transição. É absolutamente óbvio que os avanços dos anticilones polares admitem infinita variedade de maneiras mas, era necessário simplificar a complexa realidade em um modelo que, embora, declaradamente teórico, servisse a iniciação dos alunos na análise. Eles, a medida que evoluíam pela multiplicação dos casos observados, davam-se conta de que a sucessão das quatro fases não era ocorrente daquele modo, podendo haver, por exemplo, dois ou três avanços seguidos, conforme o abastecimento do fluxo polar no extremo sul do continente; as significativas diferenças de duração das diferentes fases, a eliminação de algumas delas segundo certas circunstâncias etc., etc. $\mathrm{O}$ mal, portanto, não repousa na utilização da idéia do ciclo, dependendo da maneira como ela é utilizada. Seria descabido tratar aqui, nesta palestra, da recorrência e conspicuidade da noção de ciclo na vida humana. Principiaríamos desde a associação do homem primitivo entre fases da lua e ciclo menstrual das mulheres, atravessando um longo percurso até o nível filosófico, na teoria nietzschiana do eterno retorno. Se de um lado podemos criticar o simplismo da 
abordagem dos ciclos econômicos em nossa Historia, poderemos também, encontrar grandes méritos, sobretudo de compreensão didática, na teoria das dualidades brasileiras, na qual nosso saudoso economista Ignácio Rangel, a partir da proposta do economista russo Kondratief, nos anos vinte, arquitetou algo que ajuda muito à compreensão de nossa formação sócio-econômica, sincronizada aos acontecimentos mundiais: Rangel (1981); Mamigonian (1987).

O início da segunda metade do século iria sediar grandes mudanças. Enquanto o mundo vivia a guerra fria, russos e americanos promoviam a corrida espacial. À era nuclear, superpunha-se, agora, a era espacial. Iniciada com o Sputnik russo (1957) culminou com a missão americana da Apolo 11, colocando o Homem na Lua (1969). Os anos sessenta representaram, talvez, o período áureo das reuniões anuais da AGB que, ao início dos setenta promovia uma assembléia administrativa em São Paulo, para uma mudança nos estudos que, dentre outras mudanças, fez passar as assembléias para uma ocorrência bi-anual. Inauguravam-se outros tempos, tanto no mundo quanto no Brasil. A mudança territorial marcada pela inauguração de Brasília (1960) foi seguida por aquela política, com a intervenção militar (1964), introduzindo violentas mudanças político-institucionais, econômicas e ideológicas, na vigência da segurança nacional, aplicada à pretensa integração econômica da Amazônia Brasileira e à abertura de grandes eixos rodoviários. A Geografia vê-se abalada pela introdução das revoluções teorético-quantitativas.

Conquanto o sopro revolucionário se dirigisse mais enfaticamente à Geografia Humana, não deixou de afetar também a Física. De um lado, a Climatologia, até então, puramente quantitativa, numa estatística elementar, esforçava-se justamente para tornarse mais qualitativa para o que, encontrava sérias limitações no tratamento estatístico vigente, para exibir sua dinâmica. A Geomorfologia, atingido o estatuto dinâmico, enfatizando os processos, já beirava um estágio que perseguia aquela dinâmica até mesmo em tentativas experimentais, associando-se aos estudos pedológicos e à geologia quaternarista. Assim, as técnicas quantitativas revolucionárias canalizavam-se para a geometria da drenagem hidrológico-fluvial. Em meio a toda essa efervescência permito-me extrair e relembrar aqui, acima da melée quantitativa, duas contribuições de Ab'Saber, pelo que elas encerraram de influência útil sobre a comunidade de geógrafos nacionais. No contexto singelo da revista Orientação, editada pelo extinto Instituto de Geografia da USP, Ab'Saber nos apresenta uma magistral síntese, em texto e expressivo cartograma, rotulado Domínios Morfoclimáticos e Províncias Fitogeográficas do Brasil (Ab'Saber,1967). Sua difusão foi considerável, sendo o referido cartograma reproduzido (quase sempre sem menção do autor) por livros didáticos e artigos, sendo difícil deixar de vê-lo estampado nas provas de Geografia dos exames vestibulares às Universidades. Um outro trabalho, mais dirigido a especialistas, representa a síntese da contribuição teórica de Ab'Saber à Geomorfologia feita no Brasil. Trata-se de um excerto de uma de suas teses acadêmicas na USP, apresentado como artigo na Revista Brasileira de Geografia e intitulado Uma Revisão do Quaternário Paulista: do presente para o passado (Ab'Saber, 1969). Neste trabalho ele explicita sua diretriz teóricometodológica calcada no tríptico: compartimentação, estrutura superficial da paisagem e fisiologia da paisagem. Este último nível ensejou, por algum tempo, a vigência de uma disciplina do currículo de graduação em Geografia no Departamento da FFLCH da USP, da qual eu tive o privilégio de ministrá-la. Este referencial teórico de Ab'Saber, pela sua abertura, propiciava amplas conexões a outras estratégias metodológicas, notadamente a conciliação do esquema daviseano com aquelas mais integrativas, em torno do conceito complexo de paisagem da escola alemã (Landschaft Oekologie).

O segmento temporal entre 1968 e 1973 é abalado por uma séria concentração de eventos da maior relevância que, superpondo-se cumulativamente, vão fazer com que este qüinqüênio possa ser credenciado como o muito provável ponto de mutação a partir do qual ingressamos na grande crise histórica na qual estamos mergulhados e que caracteriza esta virada de séculos, soleira do novo milênio. Alguns acontecimentos, como fenômenos de dinâmica progressiva, ultrapassando uma significação pontual do evento episódico, desenvolveram-se pelos anos sessenta e setenta. Assim foram os movimentos de rebelião juvenil contra as guerras, os valores burgueses vigentes, que desembocaram na ideologia do flower power, associada à evasão dionisíaca nos alucinógenos, arte psicodélica, etc.. A revolução sexual, com o advento da pílula anticoncepcional, os movimentos reivindicatórios de liberação da mulher, estão nesta categoria. Liberação feminina que se reflete expressivamente na moda. Se Coco Chanel, no inicio dos anos vinte, liberou as mulheres do espartilho e levantou-lhes as saias, agora, nos sessenta, Mary Quant levanta-lhe mais ainda nas mini shirts. E as feministas americanas queimam os porta-seios. No quadro apesar de suas limitações já apontadas - procurei registrar eventos datados, indicadores de mudanças relevantes. A sobrecarga foi assinalada por uma régua vertical, destacando o qüinqüênio iniciador da grande crise que atravessamos, vestíbulo da nova modernidade. Acompanhemos, no quadro, a menção dos eventos, seguindo de baixo para cima.

Se bem que numa convergência de idéias de alguns cientistas (Cordoni, 1968), a novidade da Tectônica de Placas surgiu em torno de 1968, tendo em vista as contribuições de Morgan (1968), Lê 
Pichon (1968) e Isacks, Oliver e Sykes (1968) que veio trazer nova interpretação à teoria de Wegener (1915). Neste mesmo 1968, numa outra curiosa convergência, surgiram na França, com Bertrand, e na então URSS, com Sotchava a proposta integrativa do novo paradigma dos Geossistemas. De importância fundamental para a Geografia, desde que preconizada com tentativa de uma Geografia Física Global, esta proposta visou, desde o início, um esforço de antropização do sistema. Ao longo de trinta anos, grandes passos foram dados nessa tentativa de referencial teórico para uma análise integrada do complexo geográfico, sem que se possa considerá-la com meta plenamente alcançada. Abstenho-me de alongar-me sobre este tópico porquanto já dei o meu testemunho sobre esta busca no meu trabalho entitulado Geossistemas: a estória de uma procura (Monteiro, 2000). Ainda em 1968 deu-se um fato, altamente significativo para o andamento da Geografia no Brasil. Infelizmente trata-se de um registro negativo posto que evidencia o declínio de importância da Geografia no IBGE. Já transmudado em uma Fundação, a Geografia no IBGE, embora aparentemente revigorada pela adesão às técnicas quantitativas e à moda da teoretização - proclamada oficialmente para todo o país na realização de uma conferencia especial (CONFEGE,1969), os geógrafos daquele quadro institucional foram, paulatinamente, declinando em prestígio. Isto se comprova quando registramos que a antiga tarefa de elaborar a divisão regional passa a ser tarefa transferida aos economistas do Instituto de Pesquisas Econômicas Aplicadas (IPEA). Os geógrafos da Divisão de Geografia do IBGE limitaram-se a elaboração de um considerável acervo de cartogramas, aglutinados na obra Subsídios à Regionalização (IBGE, 1969), oferecida, aos economistas. Continuava, assim, a ascensão da Economia, principiada no meio do século. Os estudos geográficos, visando a regionalização perseguiam a definição de micro regiões homogêneas e o estudo de Redes Urbanas, agora subordinadas a técnicas quantitativas, sobretudo aquela da análise fatorial. O conteúdo da Revista Brasileira de Geografia, desta época, é essencialmente teoréticoquantitativo, assinalando o princípio de decadência daquela prestimosa publicação. Mas a revolução em foco foi acontecimento de temporalidade seqüencial que, neste quadro, ficará marcado pelo evento CONFEGE.

Outro movimento importante, coincidente com este período de cinco anos, mas não se restringindo a seus limites, foi aquele de um extraordinário avanço na Ciência. Curiosamente, enquanto se exaltava a imperiosa necessidade de matematização e afirmação em leis universais, aconteciam importantes pesquisas que traziam dúvidas - mas sobretudo novas perspectivas - sobre o que a revolução insistia. Estas importantes inovações constituem um terceiro mo- mento que, junto aquele brilhante momento do início do século, mais aquele outro induzido pelo esforço dirigido à segunda guerra mundial, têm se conduzido, sem solução de continuidade, ao longo de todo o século XX. O espaço disponível no quadro seria insuficiente a registrar estas importantes aquisições, dentre as quais eu procurei inteirar-me e registrá-las em minha obra de despedida da pesquisa climatológica, intitulada Clima e Excepcionalismo: conjecturas sobre o desempenho da atmosfera como fenômeno geográfico. Em seu capítulo IV insistira em que são enriquecimentos fundamentais no desvelamento de sistemas de alta complexidade, de novas geometrias (fractais) até a Teoria do Caos. Difícil de registrar estas obras no quadro as apresento nas referências bibliográfico, assinaladas por um asterístico.

Insistindo ainda em 1968, lembro a realização do Simpósio realizado em Paris, pela UNESCO, sobre os problemas ambientais, evento este que prenuncia a Conferência de Estocolmo, em 1972, que será o legítimo marco da eclosão da Questão Ambiental, uma das facetas importantes na nossa atual crise. Também, 1968 é o ano que registrou a rebelião dos jovens franceses na turbulenta Primavera de Paris, da qual resultaria a reformulação da estrutura universitária francesa, inclusive fragmentando a tradicional Sorbonne, em várias unidades.

Para nós, no Brasil, 1968 foi o ano de implantação do Ato Institucional $\mathrm{n}^{\mathrm{o}} .5$ enquanto, para mim, pessoalmente foi o ano de meu ingresso na Universidade de São Paulo, em seguida a obtenção de meu título de doutor, no ano anterior. Ali, concomitantemente na docência junto ao Departamento e na pesquisa no Laboratório de Climatologia do IGEOG-USP, nos vinte anos seguintes, iria continuar a perseguir uma melhoria nos estudos climatológicos, a partir da base iniciada em Florianópolis e nas conquistas alcançadas em Rio Claro. Em 1972, consoante a reformulação nos cursos de Pós-Graduação eu introduzia a disciplina Introdução à Climatologia Urbana, consubstanciada pela proposta teórica (Monteiro, 1976) que estaria fadada a um acolhimento entre nulo e lento, para revelar-se e colher os seus primeiros frutos nos anos noventa.

Retornando ao ponto de mutação, e como provável marco delimitador no qüinqüênio em pauta, deve-se registrar a crise dos combustíveis, desencadeada pelos árabes do petróleo em 1973. A partir daí, prosseguimos nas convulsões da grande crise histórica que atravessamos e que, muito provavelmente penetrará pelo princípio do século entrante. Penetramos, assim, num passado mais recente que, por tão próximo e tão tumultuado, dificulta o discernimento para extrair as relevâncias e obscurece o horizonte projetivo, Contudo, atrevo-me à ousadia de apontar, ainda, alguns fatos brasileiros que me parecem aflorar. Lembraria a atuação, a partir de 1973, do Projeto RADAM, 
planejado inicialmente para a Amazônia e posteriormente ampliado para o território nacional. Além dos benefícios trazidos na revelação de riquezas minerais e aprimoramento ao sistema cartográfico, aquele projeto desempenharia um relevante papel na formação de pessoal tanto nas técnicas de análise das imagens, em gabinete, quanto nas observações diretas em sobrevôos de controle e pesquisa de campo. Neste particular, dentre outras especialidades, foi marcante o número de técnicos no campo da Geomorfologia. Até seus fins, ao término dos anos oitenta, seja pela documentação gerada para o CPRN - um acervo inestimável - seja pela formação de pessoal, incorporado aos quadros do IBGE (Setor de Recursos Naturais) e disperso por várias universidades, órgãos de pesquisa, públicos e particulares, aquele projeto desempenhou relevante papel no enriquecimento de informação para a Geografia do Brasil.

Outro fato merecedor de registro parece-me aquele, ocorrido em 1974, que assinala a edição dos primeiros manuais de Geomorfologia, em nosso país, ambos provenientes de Rio Claro, de seus docentes Antonio Christofoletti e Margarida Penteado Orellana. Neste setor didático não deve ser esquecida a colaboração pioneira de Antonio Teixeira Guerra com o seu Dicionário de Geomorfologia. Principiada desde 1949, após o retorno daquele colega dos seus estudos na França, esta obra seria editada pelo IBGE, nos anos sessenta, em sucessivas edições, que prestaram grande serviço aos estudantes de Geografia universitários.

Entre o dicionário e os primeiros manuais pode-se registrar, também, as seguintes obras auxiliares à Geomorfologia. Em 1964 o IBGE edita uma coletânea de fotos, rotulada Exercícios e Pratica de Geomorfologia, com legendas organizadas pelos Geógrafos da Divisão de Geografia: Antônio Teixeira Guerra, Alfredo José Porto Rodrigues, Carlos de Castro Botelho, Gelson Rangel de Lima e Jorge Xavier da Silva. Em 1973, o IBGE lançava outra coletânea de fotos, comentários organizados por Celeste Rodrigues Maio, rotulada Geomorfologia do Brasil.

Desde a reformulação estatutária de 1970, passando a assembléias gerais de dois em dois anos, a AGB via-se acrescida de enorme número de associados, predominantemente estudantes universitários, o que implicará num novo período na vida daquela entidade. Em 1978, a assembléia geral realizada em Fortaleza foi sede de um sério conflito que iria inaugurar uma nova fase na AGB. Dentre aquele tumulto, de várias implicações, pode-se destacar que aquele evento assinalou, de modo bem claro, a forte reação ao movimento teorético-quantitativo, e o desencadeamento, entre nós, da revolução crítico-radical sob forte influência dos marxismos. De certo modo, uma repercussão nativa do que nos vinha do hemisfério norte, divulgado, sobretudo, pelas revistas. Hérodote e Antipode. Sem que lhe possa ser imputada toda a culpa, esta facção ajudou muito o crescente afastamento que já se vinha produzindo entre Geografia Humana e Física entre nós. A crescente pressão interna nos Departamentos de Geografia das nossas universidades para, nas revisões curriculares, diminuir as disciplinas naturais em proveito das sociais, aliou-se outra discriminação, das comunicações de Geografia Física no temário dos encontros da AGB. Disto resultou uma natural resposta na criação dos Seminários de Geografia Física Aplicada, inaugurado na primeira semana de dezembro de 1984, em Rio Claro e sobre o que já tratei num artigo para a revista francesa L'Espace Géographique (Monteiro, 1989). O aumento considerável de participantes e o interesse crescente, desembocaram no desdobramento dos simpósios de Climatologia Geográfica e este próprio de Geomorfologia, igualmente realizados a cada dois anos.

Enquanto atravessamos a crise, da qual sobressai uma preocupação econômica marcada por um ambíguo neo-liberalismo onde o capitalismo, após o malogro das tentativas comunistas com o desmonte da URSS e das Repúblicas Populares da Europa Central, persegue uma globalização conduzida pelo mercado; onde a aproximação produzida nas comunicações pela tecnologia eletrônica acentua a separação entre os países ricos -o fechado clube dos sete - e os pouco remediados cercados por maioria de pobres e miseráveis, parece estar havendo - pelo menos no escopo da Geografia - uma saturação com este determinismo econômico. Passando pela experiência de uma Geografia da Percepção, emerge uma Geografia Humanística, da qual, ao lado das relações com a Literatura, emerge também uma nova onda de Geografia Cultural, que se vêm firmando entre nós no Brasil. Também desponta uma preocupação em focalizar em diferentes atividades humanas, uma abordagem dirigida às diferenças de gênero, transposta da antropologia para o contexto gráfico. É até muito sintomático, e mesmo esclarecedor que, em meio a este turbilhão de mudanças, a medida que surgem tendências novas, voltadas ao futuro, ressurgem também antigas preocupações de revivals, o que converge para aquela concepção de um tempo espesso ou tríbio, na fusão de passado, presente e futuro.

Neste contexto a Geomorfologia que se faz no Brasil, beneficiada pela preocupação com a dinâmica processual, pela aliança com a Pedologia e Geologia no denominador comum do quaternarismo - para o que a filiação ao IBEQUA (1986) é um indicador temporal - encontra-se hoje numa fase muito promissora, do que a realização deste Simpósio, do seu temário e do conjunto das atividades programadas, é um expressivo comprovante.

Tenho em minha frente um auditório especial onde estão reunidas expressivas figuras da produção geomorfológica deste país - geógrafos e especialistas das ciências afins - pelo que me eximo de qualquer 
preocupação de especular sobre o caráter atual. Reservo-me apenas para, na terceira e última parte desta palestra, acrescentar as minhas impressões. E estas serão realmente impressões de alguém que, fora da militância ativa da prática geográfica, tem fruído de participar de assembléias geográficas várias, nestes três últimos anos, após o retorno de uma estada de dois anos no Japão (1995-1997).

\section{DO MEAdo DO SÉCULO AO SEU FINAL (Unidade ou Desintegração na Geografia? )}

Fosse pelas mudanças ocorridas na AGB e suas assembléias, fosse pelo meu enredamento com comissões da UGI - Environmental Problems (1976 1984) e Geographical Monitoring and Forecast (1985-1988) mantive-me ausente dos fóruns geográficos nacionais. No ano de 1988, após minha aposentadoria na USP, na reunião comissional em Canberra, antecedente ao Congresso da UGI, em Sidney, encerrei minha participação nos eventos geográficos internacionais. Nos dez anos seguintes dediquei-me a escrever uma obra sobre a minha memória familiar no Piauí (1850-1950); e colaborações avulsas em Cursos de Pós-Graduação (UFSC e UFMG) e num Curso de Estudos Brasileiros na Universidade de Tenri, Província de Nara, no Japão (1995-1997).

Ao retornar do Japão, em março de 1997, passei a receber convites e a comparecer a algumas reuniões. Minha ida ao Seminário de Geografia Física Aplicada, em Curitiba (1997) e aquele de Climatologia Geográfica, em Salvador (1998), foram gratificantes. Eles mostraram-me, pelo temário, pelo elevado número de participantes (superior a 300) e pela qualidade das comunicações e debates, que o interesse pela Geografia Física era entusiasmante. Naquele de Climatologia, em Salvador, tive a grata surpresa de encontrar 38 comunicações sobre a temática Climas Urbanos, discutidas em quatro sessões de trabalho, por colegas de diferentes regiões brasileiras. Até então eu vinha sentindo um certo desalento por constatar que minha contribuição naquele setor, incluindo o credenciamento de uma disciplina de Pós-Graduação na USP e uma proposta teórica (Monteiro,1976) não frutificara. Deime conta, então, que a coletânea de artigos consagrada àquela temática, no número 9 da revista GEOSUL, da UFSC, tinha conseguido, efetivamente, motivar a nova geração de nossos geógrafos.

A consulta aos periódicos geográficos - consideravelmente aumentados - revelava-me que na vertente da Geografia Humana, a ênfase no social se acentuara ainda mais, o que é compreensível e louvável a não ser quando se depara com assertivas do tipo já que a natureza está suficientemente conhecida e sob controle, a Geografia hodierna tem que privilegiar o social. Uma estranhíssima opinião, sobretudo para o caso brasileiro. Felizmente a própria produção em
Geografia Física desacredita tal opinião. Em visita ao meu antigo Departamento na USP constatei que, no ano anterior, as dissertações e teses ali produzidas em Humana e Física estavam em número equivalente.

Enquanto eu ouvira, no Seminário "Geografia 2001", realizado em setembro de 1999, na Universidade Federal de Sergipe, em Aracajú, assertivas de que a questão ambiental era uma falsa questão na Geografia, eu constatava que a vigência daquela questão estava desempenhando um importante papel em integrar nas pesquisas de Geografia Física, já que, em muitos casos, os trabalhos apresentados revelavam um nítido direcionamento às componentes humanas. E, agora mesmo, este Simpósio de Geomorfologia, não deixa duvidas sobre isto. Como atenuante a esse indesejável afastamento constatou-se que, a própria reunião da $\mathrm{AGB}$, realizada no próximo passado agosto, em Florianópolis, sob a Presidência de Carlos Walter Gonçalves, procurou imprimir um cunho de aproximação, tanto na composição do temário quanto pelo fato de que a conferência de abertura, foi proferida pelo nosso colega $\mathrm{Ab}$ 'Saber. Estes são fatos muito auspiciosos que me dão novo alento. E será no sentido de contribuir para um maior entrosamento na comunidade nacional de geógrafos que eu me esforçarei, no fecho dessa nossa conversa, para advogar pela causa da unidade na Geografia. Unidade esta que - como em toda unidade não implica em uniformidade, desde que a diversidade é caráter inerente tanto à Natureza quanto às Sociedades Humanas.

A mim, parece-me muito estranho que, enquanto tudo leva a crer que a Ciência, em nossos dias, assume uma atitude menos pretensiosa e quando se propugna elaborar um novo conhecimento (episteme) mais conjuntivo, que a Geografia - que tinha nesse atributo um dos seus grandes trunfos, inclusive como veículo de educação - queira desfazer-se dele justo agora. Na hipótese de uma inevitável separação geradora de uma Geografia "Ciência Social" e outra "Ciência da Terra" não teria dúvidas de que esta segunda, seria sempre, e cada vez mais, antropocêntrica já que o Homem não é, meramente, um paciente, mas importante agente na organização dos espaços, sobretudo naqueles espaços concretos, euclidianos, do viés das paisagens ou geossistemas.

Meu querido colega, e grande amigo, Armen Mamigonian, não faz muito tempo (Mamigonian, 1996), ao comentar tal conflito, advertiu que :

Por isso, quando alguns propõem a inversão da relação Geografia Física / Geografia Humana, visto que na geografia tradicional os fenômenos humanos eram subordinados à base natural e, nessa inversão proposta, o natural é reduzido a recursos econômicos (matérias primas, etc.), a Geografia Física, armada do paradigma geossistema, continua 
suas pesquisas, indiferente a esse reducionismo empobrecedor e realiza mais progressos do que a Geografia Humana, pois se existem, por interferência humana, a chuva ácida ou os buracos na camada de ozônio, as massas de ar continuam deslocando-se, os vulcões não precisam pedir autorização dos governos da Nova Zelândia ou da Colômbia e nem os terremotos aos poderosos governos dos E.U.A. ou do Japão etc., etc. Afinal está na hora de se perceber, com humildade, que existem leis naturais e leis sociais, independentemente da vontade dos indivíduos. (Armem Mamigonian: A Geografia e a Formação Social como Teoria e como Método).

Eu não saberia dizer se a Geografia Física faz mais progressos que a Geografia Humana. Mas, não duvido de que esta tem mais aceitação, por vários motivos, mas, sobretudo pela pretensão humana mormente na civilização judaico-cristã - em arrogar-se ao direito de veto sobre a natureza e, mais ainda, pelo que Nietzsche apontou, na "hiperbólica ingenuidade do homem: colocar a si mesmo como sentido e medida de valor das coisas" (Sobre o Niilismo, parágrafo 12: Queda dos Valores Cosmológicos).

Não me alimenta nenhuma rivalidade. Embora seja tido como fato já consumado que, nos centros hegemônicos do saber e do poder mundial Geografia Física e Geografia Humana já se tenham apartado, seria uma pena que isso viesse a acontecer no Brasil. Meu apelo pela unidade repousa no fato de que a Geografia tem seu maior encanto naquilo que ela encerra não como ciência analítica mas pelo que acrescenta à compreensão filosófica. Mesmo pelo seu lado Ciência, envolvida com leis naturais e sociais, não faltam estratégias lógicas no confronto de fatos das mais diversas categorias. Veja-se, por exemplo, que em fatos tão diversos quanto umidade relativa (fato físico na atmosfera), perfil de equilíbrio (fato hidrodinâmico fluvial na litosfera) e mais valia (fato econômico na economia das sociedades capitalistas) permitem aspirar-se a uma quantificação que lhes confira foros de concretude à sua condição conceitual puramente abstrata. Este esforço de sintonia ou aparentamento de atributos, ou elementos discretos, também se pode projetar, ampliadamente, para concepções mais complexas, de síntese, como clima, relevo, economia. Assim, por exemplo, parece-me absolutamente equivalente a falta de lógica em considerar-se erosão normal na gênese dos relevos quanto o estado médio dos elementos atmosféricos naquela do clima. Não sei se exorbitaria em estender o raciocínio sobre as limitações de PIB ou renda per capita para caracterizar plenamente uma economia ou um cartograma da distribuição funcional urbana para definir toda a complexidade de vida de uma cidade.

Ainda em proveito da apreciação de uma visão unitária, integradora, na Geografia, permito-me retomar o dualismo idiográfico-nomotético assinalado por Scheffer em sua crítica à Geografia do meio do século $\mathrm{XX}$. Indagaria se a visão nomotética da economia capitalista, dita neo-liberal da atual decantada globalização dispensaria aquela outra, idiográfica da realidade dos graus de desenvolvimento nacionais dos países pobres. Aqui também neste caso, os foros de normalidade caberiam aos centros hegemônicos (Clube dos Sete) que se arrogam ao direito de impor um modelo econômico à maioria absoluta de países remediados, pobres ou miseráveis, tidos como acidentais excepcionalidades.

Outra das descabidas críticas de Schaefer à Geografia é aquela de que o excepcionalismo geográfico tem suas raízes no idealismo de Kant (1756) consubstanciado no romantismo literário da cosmologia de Humboldt (1845). Bendita subjetividade artística esta que concede ao Homem o privilégio de sentir o Mundo. Mundo que é sua própria marca edificatória (ação sócio-econômica-técnica) sobre o planeta Terra, ou globo terrestre, projetado na amplidão do Sistema Solar, numa das inúmeras galáxias do universo. Daí o termo globalização (no artefato físico Terra) não dever ser sinônimo ou equivalente a mundialização (construto técnico cultural materializado pelo Homem no globo terrestre). A falta de sintonia entre o construto humano sobre o globo terrestre (ou melhor, à sua superfície) é que emerge a séria questão ambiental. Ressalta daí que a semântica de ambiente deve ligar-se construído, derivadamente, da primitiva natureza pelo Homem.

É necessário que, assim como as concepções de tempo e espaço são a priori à condição humana a relação Homem-Natureza, como preconizou Bergson, é algo que se coloca no plano transcendental. A este propósito assinalo que, no momento atual, parece haver um revival da filosofia de Bergson, pelo menos na França, onde a tese de nosso filósofo Bento de Almeida Prado, intitulada "Presença e Campo Transcental", defendida na USP em 1964, está sendo ali traduzida e editada.

Como nos aconselhou Nietzsche, mesmo o homem mais racional precisa outra vez, de tempo em tempo, da natureza, isto é, de sua postura fundamental ilógica diante de todas as coisas (Humano, Demasiado Humano, parágrafo 31: O Ilógico Necessário). E notemos, com o devido orgulho, a posição em que e companhia de quem aquele filósofo, ao analisar o paganismo grego e seu papel na organização do Estado, coloca o geógrafo: 
Em sua edificação os gregos mostraram como aquele maravilhoso sentido do típico-factual que mais tarde os capacitou a se tornarem investigadores da natureza, historiadores, geógrafos, filósofos. Não era uma lei costumeira restrita, clerical ou de casta, que deveria decidir na constituição do Estado e do culto de Estado: mas sim a mais ampla consideração da efetividade do humano. De onde tiram os gregos essa liberdade, esse sentido do efetivo? Talvez de Homero e dos poetas anteriores a ele; pois precisamente os poetas, cuja natureza não costuma ser a mais justa e a mais sábia, possuem em compensação esse gosto pelo efetivo, pelo eficiente de toda espécie, e não querem negar totalmente nem mesmo o mal: basta-lhes que ele se modere e não fira mortalmente ou envenene tudo - isto é, pensam de modo semelhante aos gregos fundadores de Estado e foram seus mestres e precursores (Humano, Demasiado Humano, parágrafo 120: O que é propriamente pagão).

Isto posto, e sem atrever-me a fazer prognósticos, nem mesmo para a primeira década do Século XXI, já que tudo indica que o volume de mudanças, superpostas e acumuladas, requer uma proporcionalmente longa crise histórica, eu me permitiria apenas sugerir algo a esta platéia de geógrafos ou cientistas da Terra que elegeram, a Geomorfologia campo específico de investigação.

Em primeiro lugar sugiro que continuem trabalhando pois que há evidências inequívocas de um considerável progresso. Também aconselharia que se mantivessem unidos, tanto nos debates específicos da Geomorfologia e, tanto quanto possível, naqueles de Climatologia Geográfica e Geografia Física Aplicada. Que não se isolem ignorando o que está sendo feito em Geografia Humana, em seus diferentes setores, pois, malgrado a obsessão social de alguns há contribuições da maior relevância. Só assim poderemos contribuir para que, numa futura avaliação - sob a égide de uma nova razão e de uma nova episteme - nos venha indicar qual das duas vertentes - Física e Humana será responsável pelo sentido e valor de uma renovada ou extinta Geografia.

O fato de que este evento acolhe também considerável número de jovens estudantes é necessário adverti-los que não fiquem preocupados e receosos com a aqui, insistentemente mencionada, Crise Histórica que atravessamos. As crises, inclusive as grandes, são fenômenos recorrentes na trajetória da humanidade. E para que este eterno retorno não seja tomado como uma maldição, recorro, a Nietzsche:

O valor de uma tal crise é que ela purifica, que ela condensa os elementos aparentados e os faz corromperem-se uns aos outros, que ela encaminha os homens de maneiras de pensar opostas a tarefas comuns - trazendo também à luz, entre eles, os mais fracos, mais inseguros, e, assim, põe em marcha uma ordenação hierárquica das forças, do ponto de vista da saúde: reconhecendo mandantes como mandantes, obedientes como obedientes. Naturalmente, à margem de todas as ordenações sociais vigentes (Sobre o Niilismo, parágrafo 53).

A sabedoria chinesa aglutina, no caractere gráfico que representa o vocábulo crise àqueles relativos a dificuldade e oportunidade. No meu ocaso como geógrafo invejo aqueles que estão no alvorecer. $\mathrm{O}$ mundo atual, em fervente mutação, requer um verdadeiro heroísmo para que venhamos a senti-lo, compreendê-lo, quiçá modificá-lo. E este desafio, em sua magnitude, requer uma Geografia mais voltada para o seio holístico da Filosofia do que para os estreitos sendeiros de u'a mera Ciência Social.

\section{Agradecimentos}

$\mathrm{O}$ autor agradece penhoradamente aos amigos: Dr. Marcos Norberto Boim pela montagem do quadro no computador (SIMBIOSE - Rua Quintino Bocaiúva, 696 F. Presidente Prudente, SP) e Drs Regina e Alvanir de Figueiredo pela colaboração no levantamento bibliográfico, digitação do mesmo, e revisão do texto.

\section{Bibliografia}

Ab'saber, A. N. Regiões De Circundesnudação PósCretácea No Planalto Brasileiro. In Boletim Paulista De Geografia $N^{o} 1$ - p. 8 São Paulo, A.G.B., Março De 1949

Ab'saber, A. N. Domínios Morfoclimáticos E Províncias Fitogeográficas Do Brasil. In Orientação, $\mathrm{N}^{\circ}$ 3, pp.45/48 São Paulo,Igeog-Usp, Março De 1967.

Ab'saber, A. N. Uma Revisão Do Quaternário Paulista: Do Presente Para O Passado. In Rev. Bras. De Geogr. Ano 31, No 4, pp.01/51. Rio De Janeiro, Ibge, Jan/Mar.1969.

Almeida, F.F. Marques de. Relevo De Cuestas Na Bacia Sedimentar Do Paraná. In Boletim Paulista De Geografia. Ano 1- No 3-pp. 21-33

Almeida, F.F. Marques de. Contribuição À Geomorfologíca Da Região Oriental De Santa Catarina In Boletim Paulista De Geografia. Ano IV No 10 - pp. 03-22. São Paulo, A.G.B., 1952. 
Bergson, H. Cartas, Conferências E Outros Escritos. Trad. Franklin L. Silva (574pp). Col "Os Pensadores", 38. São Paulo, Abril Cultural, 1974.

Beroutchachivili,N. \& Bertrand,G. Le Géosystème Territoriel Naturel In Rev. Geogr. De Pyrenéés Et Du Sud-Ouest, Vol 49, No2 pp. 167/187. Toulouse, 1978.

Bertrand,G. Paysage Et Géographie Physique Globale: Esquisse Méthodologique. In Rev. Géogr. De Pyrenées Et Du Sud-Ouest,Vol. 39, No 3 pp. 249/272. Toulouse, 1968.

Bertalanffy, L. Von. An Outline Of General Systems Theory. In British Journal Of Phylosophy Of Science. No 1, pp.139/164. London, 1950.

Bertalanffy, L. Von. General Systems Theory: A New Approach In Unity Of Science. In Human Biology,No 23, pp. 302/3361, 1951.

Bigarella, J. J. Esboço Da Geologia E Poleogeografia Do Estado Do Paraná. In Boletim N7 29. Do Instituto De Biologia E Pesquisas Tecnológicas - (P. 14) Curitiba, 1954

Blache, V. De La. Principes De Geographie Humaine 4 Ème Ed., 326pp.

Carvalho, C. M D. De. Météorologie Du BrésilPreface De Sir Napier Shaw. London, 1917.

Christofoletti, A. Geomorfologia ( 149 pp. Ilustr.) São Paulo, Blucher, 1974.

Christofoletti, A. As Teorias Geomorfológicas. In Geomorfologia, Cap. 7, pp. 126/144 Paris, Armand Colin, 1948.

Coltrinari, L. (Org.) Davis \& De Martonne. In AGB Seleção De Textos No 19 -Geomorfologia,49 pp. São Paulo, AGB, 1991.

Cotton, C. A. Landscape As Developed By Processes Of Normal Erosion ( 301pp.) Cambridge, Cambridge University Press, 1941.

Cotton, C. A. Climatic Accidents In Landscape Making (354 pp.) Christchurch, N. Zealand, Whitecombe And Pmbs, 1942.

Cotton, C. A. Geomorphology (505 pp.) New York, John Willey And Sons, 1949.

Cordani, U. G. Dados Recentes Sobre A Deriva Dos Continentes. In Boletim Do Centro Paulista De Estudos Geológicos - Geologia No 3, pp. 13/40. São Paulo, Cpeg, 1968. In Caderno De Ciência Da Terra. São Paulo, Instituto De Geografia Da USP, 1974.

Cristaller, W. Die Zentralen Orte In Suddeutshland Jena, 1933.

Dansereau, P. Introdução à Biogeografia. In Rev. Bras. De Geogr., Ano 11, No 1d, pp.03/92 Rio De Janeiro,Ibge, Jan/Mar., 1949.

Davis, W. M. The Geographical Cycle. In Geographical Journal Of The Royal Geographical Society, 14 ( 1899), pp.481/504.

Feigenbaum, M.J. (*)Metric Universality In Linear Recurrence. In Casati,G. \& Ford, S. (Editors)
Stochastic Behaviour And Quantum Hamiltonian Systems - Volta Memorial Conference, Como, 1977. Lecture Notes In Physics, No95, pp. 163/166 Berlin, Springer Verlag, 1979.

Freyre, G. Casa Grande \& Senzala - Fundação Da Família Brasileira Sob o Regime Da Econômica Patriarcal (1933) $7^{\mathrm{a} E d}$ Ilustrações de T. Santa Rosa $1^{\circ}$ Vol. (000 - 456 P) $2^{\circ}$ Vol. (459 -861 pp) Col. Documentos Brasileiros - 36 E $36^{\mathrm{a}}$ Rio De Janeiro, Liv José Olimpio Edit. 1952.

Freyre, G. Sobrados E Mucambos - Decadência Do Patriarcado Rural No Brasil. (405 pp) Biblioteca Pedagógica Brasileira. - Série 5 - Brasiliana, V. 64 São Paulo, Companhia Editora Nacional, 1936.

Guerra, A. T. Dicionário Geológico-Geomorfológico (411 pp.- Ilustr. ) $2^{\circ}$ Edição Rio De Janeiro, Ibge, 1966

Guimarães, F. M. S. Divisão Regional do Brasil. In Rev. Bras. de Geogr. Ano 3, No 2 pp. 318/ 3373. Rio de Janeiro, Ibge, Abri/Mai/Jun., 1941.

Hann, J. Handbook Of Climatology. New York, Mac Millan, 1903.

Hartshorne, R. The Nature Of Geography. In Annals Of The Association Of American Geographers, XXIX (1939), pp. 171/658

Harvey, David. Explanationin Geography (521 pp. Ilustr. ) London, Edward Arnold Publishers, 1969.

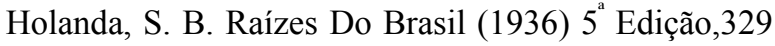
pp - Prefácio De Antônio Candido Rio De Janeiro, Liv. José Olympio Editora, 1973.

Hoover, E. M. The Location Of Economic Activity New York, 1948.

Huntington, E. Mainspring Of Civilization. New York, John Willey \& Sons, 1945.

Humboldt, A. V. Kosmos - Entworf Einer Physischen Weltbeschreibung Stutgart- Tubingen, 1845.

CONSELHO NACIONAL DE GEOGRAFIA (IBGE). Exercícios E Práticas De Geomorfologia Organizado Pelos Geógrafos: Alfredo José Portodomingues, Antonio Teixeira Guerra, Carlos De Castro Botelho, Gelson Rangel De Lima e Jorge Xavier Da Silva. Rio De Janeiro, IBGE, 1964.

CONSELHO NACIONAL DE GEOGRAFIA (IBGE). Subsídios À Regionalização Apresentação De Marilia Gosling Velloso Brochura, 27x30 Cm- 206 Pp +5. Mapas, Cartogramas E Tabelas, Parcialmente A Cores. Rio De Janeiro, Fundação IBGE, 1968.

Kant, I. Physische Geographie ( 1756 ) Koeningsberg, F.T. Rink Ed., 1802.

King, L. Morphology Of The Earth. Edinburgh, U.K., 1962. 
Koppen, W. Klimakunde: Algemeine Klimalehre. Leipzig, Sammlung Gosschen, 1906.

Koppen, W. Climatologia, Com Un Estudio De Los Climas De La Tierra. Trad. De Pedro R. Henddricks Perez - 478 pp. Ilustr Mexico, Fondo De Cultura Economico, 1948.

Lobeck, A. K. Block Diagrams. (206 pp.) New York, John Willey And Sons, 1924. (Revisions By Emerson Trussell Book Co. Amherst, Mass., 1958).

Lobeck, A. K. Geomorphology - An Introduction To The Study Of Landscapes (731 pp., Ilustr.) New York, Macgraw - Hill Book Co. Inc., 1939.

Loczy, L De A. \& Ladeira, E.A. Geologia Estrutural E Introdução À Geotectônica. São Paulo, Ed. Edgard Bluchner Ltd, 1980.

Lorenz, E. (*) Deterministic Nonperiodic Flow In Journal Of The Atmospheric Science, Vol. 20 ( 1963 ) P.130.

Lorenz, E. The Problem Of Deducing The Climatic From The Governing Equations. In Tellus, NoXVI ( 1964 ) pp. 01/11

Losh, A. Die Räumliche Ordnung Der Wirtschaft Jena, 1940.

Maack, H. Breves Notícias Sobre A Geologia Dos Estados Do Paraná e Santa Catarina. In Arquivos De Biologia E Tecnologia. Vol. II Curitiba, 1947.

Maack, H. Geografia Física Do Estado Do Paraná( 350 pp, Ilustr. ) Curitiba, S.C.P., 1968.

Maio, C. R. Geomorfologia Do Brasil: Fotos E Comentários Centro De Cooperação Técnica Do Digeo Rio De Janeiro, Fundação IBGE, 1973.

Mamigonian, A. Introdução Ao Pensamento De Ignácio Rangel. In Geosul, No 3, Ano II, pp.63 /70 Florianópolis, CCH-UFSC, $1^{\circ}$ Semestre 1987.

Mamigonian, A. A Geografia E A "Formação Social" Como Teoria E Como Método. In Sousa, Maria Adélia Aparecida De (Organizadora) O Mundo Do Cidadão Um Cidadão Do Mundo pp.198/200 São Paulo, Hucitec, 1996

Mandelbrot, B. (*)The Fractal Geometry Of Nature New York, Freeman, 1977.

May, R. M. (*)Biological Populations With Non Overlappping Generations: Stable Points, Stable Cycles And Chaos. In Science, Vol. 186 Novembeer Tje 15 Th, 1974 pp. 645-647.

Martonne, E. De. Traité De Géographie Physique (3 Vol.) Paris, Lib. Armand Colin.1922 Várias Edições Entre 1922 E 1951. A Edição De 1948 Foi Traduzida E Publicada Na Coletânea Rotulada Panorama Da Geografia, Vol. 1 Lisboa, Editora Cosmos, 1953.
Moraes Rêgo, L. F. De. Notas Sobre A Geomorfologia De São Paulo E Sua Gênese São Paulo, Instituto Astronômico E Geofísico, 1943.

Monteiro, C. A. De F. Geomorfologia Da Região Sul. In Geografia Regional Do Brasil - Vol. IV Tomo 1 - Cap. 1, pp.15/79 Rio De Janeiro, IBGE, 1963.

Monteiro, C. A. De F. O Clima Da Região Sul. In Geografia Regional do Brasil - Vol. IV Tomo 1 Cap. 3, pp.117/169 Rio De Janeiro, IBGE, 1963

Monteiro, C. A. De F. A Dinâmica Climática e as Chuvas No Estado De São Paulo - Estudo Geográfico Sob Forma De Atlas - 1964. São Paulo, Instituto De Geografia Da USP, 1973.

Monteiro, C. A. De F. Teoria e Clima Urbano(181 pp. Ilustr.) Série "Teses e Monografias" N²5 São Paulo, Instituto De Geografia Da USP, 1976.

Monteiro, C. A. De F. Derivações Antropogênicas Dos Geossistemas Terrestres No Brasil e Alterações Climáticas: Perspectivas Urbanas E Agrárias Ao Problema Da Elaboração De Modelos De Avaliação Simpósio A Comunidade Vegetal Como Unidade Biológica, Turística E Econômica- Anais - Publicação N 15 Da Academia De Ciências Do Estado De São Paulo (Aciesp) pp. 43/76, Ilustr. São Paulo, Aciesp, 1978.

Monteiro, C. A. De F. A Geografia No Brasil (19341977):Avaliação e Tendências (155pp., Ilustr.) Série "Teses e Monografias", N 37 São Paulo, Instituto De Geografia da USP, 1980.

Monteiro, C. A. De F. Travessia Da Crise (Tendências Atuais $\mathrm{Na}$ Geografia). In Rev. Bras. De Geogr. N 50 -Edição Especial -Tomo 2 pp. 127/150 Rio De Janeiro, Fundação IBGE, 1988.

Monteiro, C. A. De F. Les Orientations Actuellesde La Géographie Physique Au Brésil In L ' Espace Géographique, 1989,No.3, pp.204/208 Paris, Doin, 1989.

Monteiro, C. A. De F. Clima e Excepcionalismo (Conjecturas Sobre O Desempenho Da Atmosfera Como Fenômeno Geográfico (241 pp. Ilustr. ) Florianópolis, Editora Da UFSC, 1991.

Monteiro, C. A. De F. Geossistemas - A História De Uma Procura (127 pp. ,Ilustr. 40 Figuras + Anexo. São Paulo, Editora Contexto, 2000.

Passarge, A. Die Kalahari - Versuch Einer Physischgeographischen Darstellung Der Sandfelder Súdafrikanischen Beckens. ( 822 pp) - Atlas (21 P) Berlim, 1904.

Penck, A. Die Letzten Krustenbewegungen. In Den Alpen. In Geol. Foreningen, Kli (1922) pp. 602-622 Stockholm, 1922. 
Penteado, M. M. Fundamentos De Geomorfologia (141 pp.+ 46 Fotos E 77 Figuras) Biblioteca Geográfica Brasileira, Série D, No. 3 Rio De Janeiro, IBGE, 1074.

Prado Jr, C. Formação Do Brasil Contemporâneo (391 pp.) São Paulo, Liv. Brasiliense Editora, 1963.

Prigogine, I \& Stenghers, I. (*)La Nouvelle Aliance Métamorphose De La Science2 Nde Édition, 443 pp + Anexes. Paris, Gallimaard, 1986.

Rangel, I. A História Da Dualidade Brasileira. In Revista De Economia Política, No 4 São Paulo, Editora Brasiliense, 1981.

Thunen, J. H. V. Der Isoliert Staat. Rostock, 1842.

Semple, H. C. Some Geographical Causes Determining The Location Of Cities. In Journal Of School Geography, Nº. 10, 228pp. October, 1897.

Serra, A. \& Ratisbonna, L. Ondas De Frio Na Bacia Amazônica Serviçode Meteorologia Do M. Da Agricultura,1941 Transcrito In Boletim Geográfico, Ano III, No. 26, pp 172/206 Rio De Janeiro, IBGE, 1945.

Schaefer, F. Exceptionalism In Geography: A Methodological Examination. In Annals Of The Assoc. Of American Geographers, Vol. 43, No. 3, September. 1953.

Sternberg, H. O' R. Enchentes E Movimentos Coletivos Do Solo No Vale Do Paraíba Em Dezembro de 1948: Influência Na Exploração Destrutiva Das Terras. In Ver. Bras. De Geogr., Ano XI, No 2, pp. 223/262 Rio De Janeiro, IBGE, 1949.

Sorre, M. Les Fondements De La Géographie Humaine Tome 1 - "Les Fondements Biologiques - Ch. 1 "Le Climat" 13 Édition. Paris, Librairie Armand Colin, 1951

Surell, A Etudes Sur Les Torrents Des Hautes Alpes. Paris, 1841.

Taylor, T. G. Urban Geography: A Study Of Site, Evolution, Pattern And Classification In Villages, Towns And Cities. London, Methuen \& Co, Ltd, 1949.

Thom, R. (*)Structural Stability And Morphogenesis New York, Benjamim, 1972.

Thom, R. Parábolas e Catástrofes - Entrevista Sobre Matemática, Ciência E Filosofia Concedida A Giulio Giorello E Simona Monni. Tradução Portuguesa De Mario Brito Apartir Da Edição Publicada Por Saggiatorre, Milão, 1980 Italiana, Lisboa, Publicações D. Quixote, 1985.

Tricart, J. Les Caracteristiques Fondamentales Des Systèmes Morphogénétiques Des Pays Tropicaux Humides. In L' Information Géographique, Année 25, No.4, pp.155/169 Paris, Septembre/Octobre, 1961.
Tricart, J. Principes Et Méthodes De La Géomorphologie Paris, Masson \& Cie., Editeurs, 1965.

Wooldridge, S.W. The Geographer As Scientist Essays On The Scope And Nature Of Geography (299 pp., Ilustr. 30 Figures.) London, Thomas Nelson \& Sons Ltd, S/D

(*) As obras assinaladas com asterístico são aquelas que no Quadro aparecem pontuadas no conjunto "grandes acréscimos", na barra "ciência-tecnologia", entre 1964 e 1976. 
Monteiro, C. A. de F. / Revista de Geomorfologia, volume 2, nº 1 (2001) 